\title{
フローインジェクション分析の反応管内の流れを栓流に 近付けるための回転かくはん技術の開発
}

\author{
平川 清*, 西田 正志*, 吉田 烈*, 石井 大道 ${ }^{\circledR *}$ \\ Development of the rotation mixing technology for \\ approaching to plug-flow in a FIA reaction tube
}

Kiyoshi HiraKawa, Masashi NishidA, Isao YoshidA and Daido IsHII ${ }^{*}$

"Division of applied chemistry, Graduate school of Kumamoto institute of technology, Ikeda, Kumamotoshi, Kumamoto 860-0082

(Received 11 March 1998, Accepted 27 April 1998)

The new technology for approaching plug flow in a flow-injection analysis was developed. For that purpose, a flexible fused silica capillary of $0.35 \mathrm{~mm}$ outer diameter as the axis of rotation, for example, was inserted into a whole reaction tube of $1.0 \mathrm{~mm}$ inner diameter, $100 \mathrm{~cm}$ length. The obtained FIA signal was improved to be a symmetrical, such as a Gauss curve. A plug containing the sample and reagents was mixed only in the direction of the radius, and did not mix in the direction of the stream. The diffusion of the injected solute was controlled in the reaction tube. The mixed stream in the reaction tube was changed into plug flow due to the effect of the axis of rotation. This method was also applied to teflon tubing of $0.5 \mathrm{~mm}$ inner diameter, $100 \mathrm{~cm}$ length used in a normal FIA system. This new technology was also demonstrated for the FIA reaction of iron(III) with acidic KSCN.

Keywords : the axis of rotation; plug flow; diffusion control; FIA.

\section{1 緒 言}

フローインジェクション分析法（FIA）では，例えば 内径 $0.5 \mathrm{~mm}$, 長さ $1 \mathrm{~m}$ 程度の中空管中に適当な液体を 連続的に $1 \mathrm{ml} / \mathrm{min}$ 程度の流量で流しておき，そこへ試 料溶液を少量注入すると, 注入された試料は発色反応な どを伴って一つの試料ゾーンを形成して検出器に向かっ て輸送され, 試料物質が検出器のフローセルを通過する ときの吸光度などの変化がピーク状で検出される．ここ で得られる信号は, 管の内径, 管の長さ, 液体の流量,

\footnotetext{
* 熊本工業大学大学院工学研究科応用化学専攻：8600082 熊本県熊本市池田 4-22-1
}

試料中の溶質の分子拡散係数によって変化する．この細 管内流動現象に関しては，伊永ら゙によって詳しく解析 され, 数值解析やシミュレーション, 実験的手法などに より明らかにされている，又，中空管内に少量注入した 試料の拡散に関しては, Taylor-Aris モデル27が知られて おり, 軸方向拡散を体積標準偏差 $(\sigma v)$, 単位を $\mathrm{cm}^{3}$ で 示すと,

$$
\sigma v^{2}=\frac{\pi r^{4} L Q}{24 D_{\mathrm{m}}}
$$

の関係がある.ここで $r$ は中空管の半径 $(\mathrm{cm}), L$ は長 
さ $(\mathrm{cm}), Q$ は体積流量 $\left(\mathrm{cm}^{3} / \mathrm{s}\right), D_{\mathrm{m}}$ は分子拡散係数 $\left(\mathrm{cm}^{2} / \mathrm{s}\right)$ である. 本水ら ${ }^{3)}$ は, 内径 $0.025 \mathrm{~cm}$, 長さ 75 $\mathrm{cm}$ の反応管を用い, 流量を $0.1 \mathrm{ml} / \mathrm{min}$ とし, 従来の FIA の利点を損なうことなく, 廃液発生量などを 10 分 の1 以下としたマイクロフロー方式 FIA の開発を行っ ており, 環境水中の硝酸イオンなどの富栄養化成分の才 ンサイト分析を行っている.

著者ら ${ }^{4) ~}$ は, この管の内径を $0.025 \mathrm{~cm}$ とし，長さ を $30 \mathrm{~cm}$, 流量を $0.001 \mathrm{ml} / \mathrm{min}$ 程度に減少することに よって，栓流に近い状態での“超微量連続フローを用い る分析方法”を研究し, 排水中の化学的酸素消費量 (COD), 硝酸イオン, 亜硝酸イオンの定量を行った. この方法では中空管内の軸方向拡散が抑制されているた め, 得られる吸光度変化の信号はシャープとなり, 少量 の試料体積によって定常状態での測定が可能であること を明らかにした。

一方, 通常の FIA での栓流化のための手法としては, 1）乱流で進行させること，2）管をコイル状に巻くこ とによって副次的流れを誘起すること，3）充てん物を 詰めることによって層流を壊すこと，などが知られてい $ろ^{2)}$.

そこで本研究では，上式の $D_{\mathrm{m}}$ 值を見掛け上大きくす ることによって軸方向拡散を小さくすることを考えて, “液体が層流で流れる中空管の中心部分に, 回転かくは んのために適当な太さの軸を全長にわたって挿入し, 適 当な速度で軸を回転させることによって, 中空管内の液 体をかくはんし，管内の直径方向へのかくはん効果を利 用してその流れを栓流に近付ける”ことを骨子とする新 手法を提案するものである.

\section{2 実娩}

\section{$2 \cdot 1$ 試 薬}

着色試料としては過マンガン酸カリウム溶液を用い た. 又, 発色反応には試料として $10 \mu \mathrm{gFe}^{3+} / \mathrm{ml}$ を含む $\mathrm{Fe}_{2}\left(\mathrm{SO}_{4}\right)_{3}$ 溶液を, 発色試薬としては $1.0 \mathrm{~mol} / \mathrm{l}$ 硝酸酸 性の $1.0 \mathrm{~mol} / 1$ チオシアン酸カリウム溶液を用いた。 な お，試薬はすべて和光純薬製で特級品を用いた.

\section{$2 \cdot 2$ 反応管内回転かくはん装置の試作}

内径 1.0 あるいは $0.5 \mathrm{~mm}$, 長さ $100 \mathrm{~cm}$ のテフロン管 の中心部分に, 回転かくはん軸として前者の場合は外径 $0.35 \mathrm{~mm}$, 後者の場合は外径 $0.2 \mathrm{~mm}$ のポリイミド樹脂 被覆溶融シリカキャピラリーを挿入して, 本法を実施す るために Fig. 1 に示すかくはん装置を試作した. Fig. 1 に示すように，適当なサイズの $\mathrm{T}$ 型ジョイントと回転

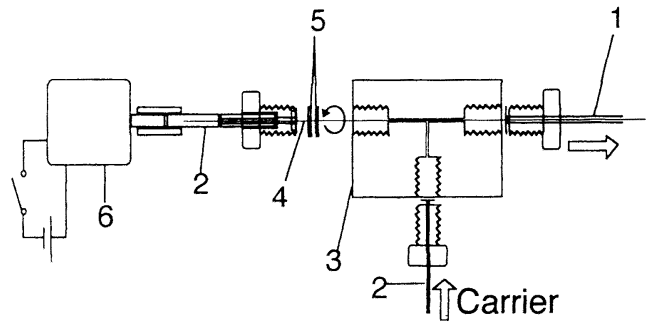

Fig. 1 Construction of joint parts for mixing in reaction tube

1: Teflon tubing of 1.0 or $0.5 \mathrm{~mm}$ i.d., $1 \mathrm{~m}$ length; 2: Teflon tubing of $0.25 \mathrm{~mm}$ i.d.; 3 : T type joint; 4 : fused silica capillary of 0.35 or $0.2 \mathrm{~mm}$ o.d. (as the axis of rotation); 5: seals (silicons seats); 6 : motor (8400 rpm)

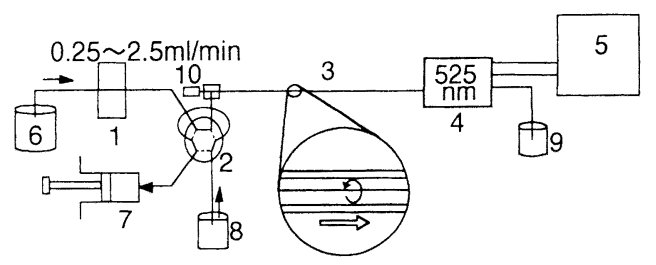

Fig. 2 FIA system

1: pump; 2: 6-way valve; 3: Teflon tubing of $1 \mathrm{~mm}$ i.d., $100 \mathrm{~cm}$ length; 4: spectrophotometric detector (light pass-length: $8 \mathrm{~mm}$ ) ; 5: recorder; 6: water in $500 \mathrm{ml}$ beaker; 7 : waste in $10 \mathrm{ml}$ syringe; 8 : potassium permanganate solution in $200 \mathrm{ml}$ beaker; 9 : waste receiver; 10: motor

かくはん用の小型モーター(マブチ製，RE-160，8400 $\mathrm{rpm}$ )を使用して，キャリヤーをテフロン管の中に円滑 に送液するとともに，溶融シリカキャピラリーを回転し てかくはんできるようにした。

\section{$2 \cdot 3$ FIA 装置}

試作した反応管内回転かくはん装置を市販の FIA 装 置に結合して, 内径 $1.0 \mathrm{~mm}$, 長さ $100 \mathrm{~cm}$ のテフロン 管について，キャリヤーとして水を使用してその効果を 試験した。用いた装置の概略を Fig. 2 に示す。試験用 の着色液として過マンガン酸カリウム溶液 $\left(4.0 \times 10^{-4}\right.$ $\mathrm{mol} / \mathrm{l}$ ）を使用した。プラグ状に注入する試料溶液の体 皘は $5 \mu$ として六方バルブインジェクター (SNK 製) を用いて注入し, 吸光度検出器 (島津製, SPD-6AV) の フローセルには $2.5 \mu \mathrm{l}$ の容量のセミミクロタイプを使用 


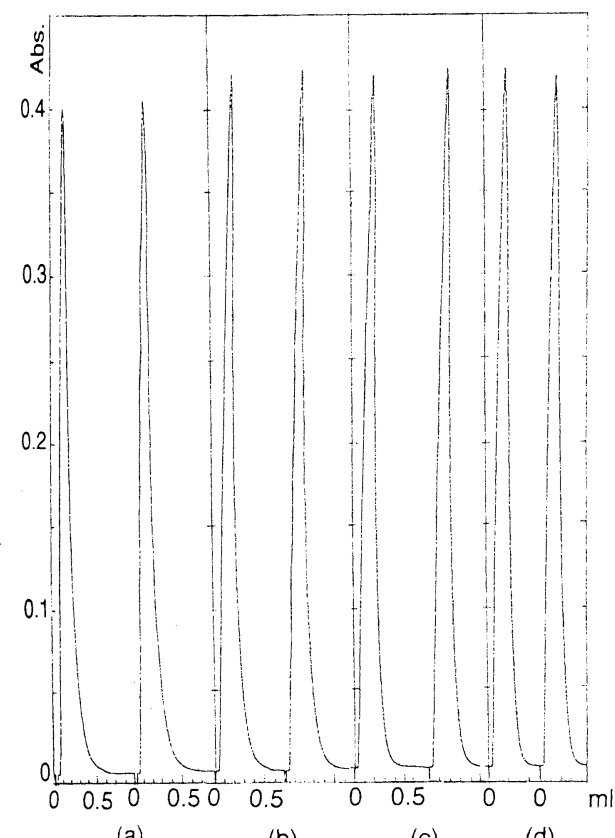

(a)

(b)

(c)

(d)

Fig. 3 Flow signals for $\mathrm{KMnO}_{4}$ without a reaction tube

Injected solute: $4.0 \times 10^{-4} \mathrm{~mol} / 1 \mathrm{KMnO}_{4}(5 \mu \mathrm{l})$; Carrier: water; Wavelength: $525 \mathrm{~nm}$

した. 記録計にはインテグレーター（日本分光製，807IT）を, 又キャリヤーの送液には, 送液ポンプ（島津 製，LC-10AD）を用いた。

\section{3 結果と考察}

\section{$3 \cdot 1$ 反応管を取り外した場合}

最初にこの装置において反応管を取り外し, 試料注入 部と検出部を直結して, 反応管の存在しない状態でのフ ローシグナルを測定した。 その結果を Fig. 3 に示す. Fig. 3の（a）は最も流量が大きく 2.5,（b）は 1.0, (c)

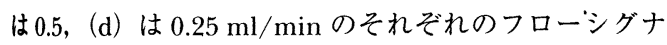
ルを示すもので, その着色試料溶液のフローシグナルの ピーク形状に大差はなく，その広がり幅（W）は約 220 川である.この值はこの FIA 装置で得られる最小の W 值であり，この装置に反応管を連結したときはこの值よ ク小さいW 值は得られないことを示している. Fig. 3 では横軸はすべて同一目盛りの送液量を示しているの で, 流量の差異によるW 值の補正の必要はない.
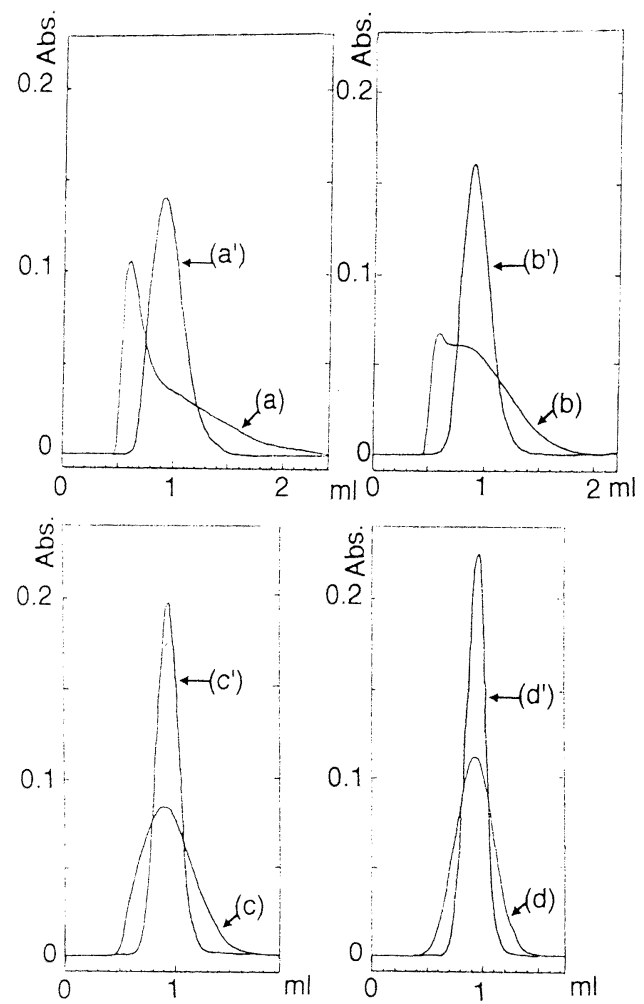

Fig. 4 Flow signals for $\mathrm{KMnO}_{4}$ using a reaction tube of $1 \mathrm{~mm}$ i.d., $100 \mathrm{~cm}$ length

(a) (b) (c) (d) were obtained by normal FIA; (a') (b') (c') (d') were obtained by proposed method; Injected solute: $4.0 \times 10^{-4} \mathrm{~mol} / 1 \mathrm{KMnO}_{4}(5 \mu \mathrm{l})$; Carrier: Water; Wavelength: $525 \mathrm{~nm}$

\section{$3 \cdot 2$ 内径 $1.0 \mathrm{~mm}$, 長さ $100 \mathrm{~cm}$ の反応管の場合}

ここで試作した装置に内径 $1.0 \mathrm{~mm}$, 長さ $100 \mathrm{~cm}$ の テフロン管を連結して Fig. 4 に示すフローシグナルを 得た.（a）の流量 $2.5 \mathrm{ml} / \mathrm{min}$ でかくはん用の軸を挿入 せずに測定を行った場合のフローシグナルに，(a'）の かくはんを行った場合のフローシグナルを重ねて示した ものであり，（b）（b'）は流量 1.0，（c）（c'）は流量 0.5, (d)（d'）は流量 $0.25 \mathrm{ml} / \mathrm{min} の$ 各同一流量において, 本法によるかくはんの効果を, フローシグナルのピーク 形状の違いとして明らかに示したものである．かくはん を行わない場合のピーク形状は流量の変化に伴って変化 することが認められ，これは伊永の実験結果 ${ }^{1)}$ と類似 している. そして（d）では流量が小さいためかくはん を行わなくても, 半径方向拡散が十分に行われるため軸 方向の対流分散が相対的に抑制され，そのピーク形状は 


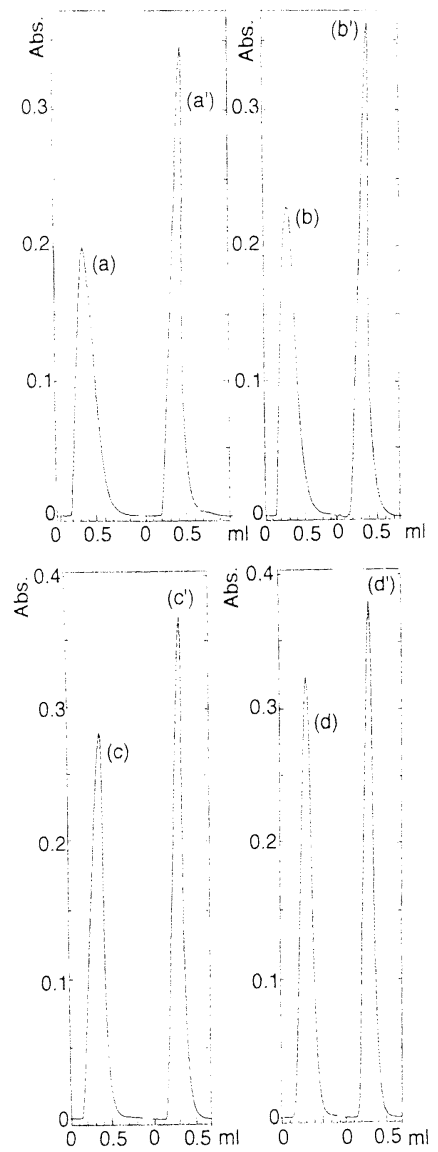

Fig. 5 Flow signals for $\mathrm{KMnO}_{4}$ using a reaction tube of $0.5 \mathrm{~mm}$ i.d., $100 \mathrm{~cm}$ length

(a) (b) (c) (d) were obtained by normal FIA; (a') (b') (c') (d') were obtained by proposed method; Injected solute: $4.0 \times 10^{-4} \mathrm{~mol} / 1 \mathrm{KMnO}_{4}(5 \mu \mathrm{l})$; Carrier: Water; Wavelength: $525 \mathrm{~nm}$

左右対称のガウス分布に近付いている．又，かくはんを 行わない場合は流量が小さくなるにつれ，ピークの頂点 の出現位置が 0.6 から $0.9 \mathrm{ml}$ 付近にしだいに変化して いくのに対し，本手法によってかくはんを行った場合で は（a'）のように流量が大きい場合でも（d'）のように 流量が小さい場合でも, 常に $0.9 \mathrm{ml}$ 付近の同位置にピ ークの頂点が出現した。

\section{$3 \cdot 3$ 内径 $0.5 \mathrm{~mm}$, 長さ $100 \mathrm{~cm}$ の反応管の場合}

試作した装置に内径 $0.5 \mathrm{~mm}$, 長さ $100 \mathrm{~cm}$ のテフロ ン管を連結し，かくはん軸に外径 $0.2 \mathrm{~mm}$ の溶融シリカ キャピラリーを用い，同様にしてフローシグナルを実測 $\left(a^{\prime}\right)$

(a)

(b)
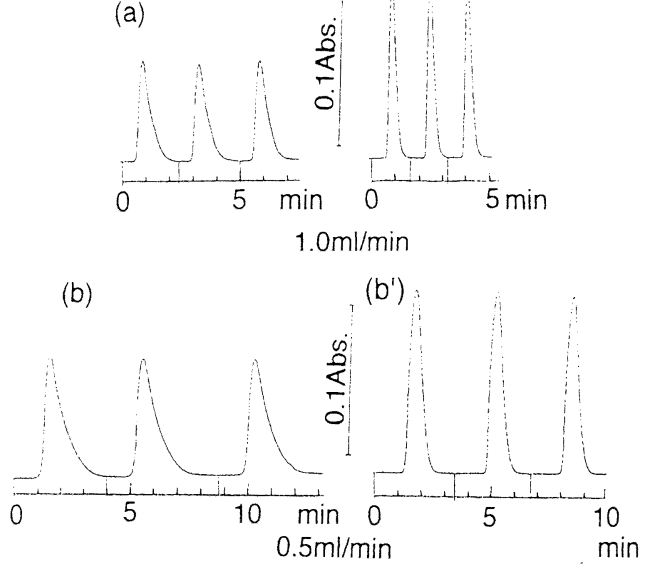

(c)

$\left(c^{\prime}\right)$

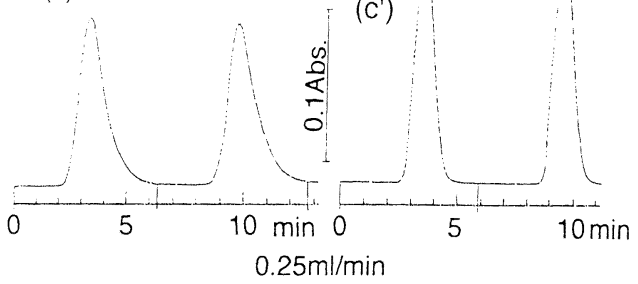

Fig. 6 Flow signals for $\mathrm{Fe}^{3+}$ by acidic KSCN method

(a) (b) (c) were obtained by normal FIA; (a') (b') (c') were obtained by proposed method; Reaction tube: Teflon tubing of $1 \mathrm{~mm}$ i.d., $100 \mathrm{~cm}$ length; Sample: $10 \mu \mathrm{g} \mathrm{Fe}{ }^{3+} / \mathrm{ml} \mathrm{Fe}_{2}\left(\mathrm{SO}_{4}\right)_{3}(5 \mu \mathrm{l})$; Carrier: acidic KSCN $(1.0 \mathrm{~mol} / \mathrm{l})$; Wavelength: $490 \mathrm{~nm}$

した．結果を Fig. 5 に示す．Fig. 5 の中の（a）と（a')， （b）と（b')，(c) と（c')，(d) と（d'）は流量がそれ ぞれ 2.5, $1.0,0.5,0.25 \mathrm{ml} / \mathrm{min}$ におけるフローシグナ ルを示すもので，本法によるかくはんの効果をフローシ グナルの変化として測定したものである．この場合は Fig. 4 の内径 $1.0 \mathrm{~mm}$, 長さ $100 \mathrm{~cm}$ の場合と比較して, 内径が 2 分の 1 になったことによって，かくはんをし ない場合のピークの $\mathrm{W}$ が相対的に小さくなっているこ とが観察される，そして本法によるかくはんの効果は流 量が大きいときに顕著であり, 又得られたピーク高さ及 びピークの W は, Fig. 3 に示した試料注入部と検出部 を直結して得られたピークの場合とほぼ同じであり, 反 応管内での広がりが本手法によって小さくなったことを 示している. 


\section{$3 \cdot 4$ FIA への応用例}

本法の FIA への適用例として鉄 (III) とチオシアン酸 カリウムの反応について検討した.Fig. 2 と同じ装置を 使用して, 試料としての硫酸鉄 (III) 溶液 $\left(10 \mu \mathrm{gFe}^{3+}\right.$ / $\mathrm{mll}) 5 \mu \mathrm{l}$ ，キャリヤー液の硝酸酸性 $\mathrm{KSCN}$ 溶液（1.0 mol/l) の流れの中に注入し, 吸光度変化を波長 490 $\mathrm{nm}$ で測定した。得られた FIA のフローシグナルを Fig. 6に示した。ここで (a) と（a') は流量 1.0，（b）と (b')は 0.5, (c) と (c') は $0.25 \mathrm{ml} / \mathrm{min}$ に扔けるかく はんをしない場合とかくはんをした場合をそれぞれ並心゙ て示したものである，又，横軸は時間で示した。

これらの実験により，化学反応を伴う通常の FIA の 测定を行う場合においても，得られるピーク形状は左右 村称でシャープとなることが確認され，本法が有効であ ることを明らかにした。

FIA の反応管内の流れを栓流に近づけるための手法と して，管内を回転かくはんする技術を開発した．本法を 朗することによって，FIAにおいても定常状態のフロ ーシグナルとしてく形状のピークが得られることが考え
られる，今後は，そのための適切な実験方法などについ て検討する予定である。

$\left(\begin{array}{l}1997 \text { 年 } 10 \text { 月, 日本分析化学会第 } 46 \text { 年 } \\ \text { 会及び } 1997 \text { 年 } 12 \text { 月, 第 } 30 \text { 回フローイ } \\ \text { ンジェクション分析講演会で一部発表 }\end{array}\right)$

\section{文献}

1) 伊永隆史: ぶんせき (Bunseki), 1995, 145.

2) 石橋信彦, 与座範政共訳: “フローインジェクシ ヨン分析法”, (1983)，(化学同人) \{J. Ruzicka, E. H. Hansen: "Flow Injection Analysis", (1981), (John Wiley \& Sons, New York) \}.

3) S. Motomizu, M. Oshima, L. Ma: Anal. Sci., 13, 401 (1997).

4) 平川 清, 吉田 烈, 石井大道: 第 57 回分析化 学討論会講演要旨集, p. 57 (1996).

5) 平川 清, 吉田 烈, 石井大道: 日本分析化学会 第 45 年会講演要旨集, p. 306 (1996)

6) 平川 清, 吉田 烈, 石井大道: 第 58 回分析化 学討論会講演要旨集, p. 137 (1997).

7) 平川 清, 吉田 烈, 石井大道: 日本分析化学会 第 46 年会講演要旨集, p. 206 (1997).

8) 平川清, 吉田烈, 石井大道: 分析化学 (Bunseki Kagaku), 47, 341 (1998).

\section{要旨}

FIA の反応管内の流れを栓流に近付けるための新しい手法として管内を回転かくはんする技術の開発 を行った．内径 $1.0 \mathrm{~mm}$ ，長さ $1 \mathrm{~m}$ のテフロン管を用い，その中心部分に回転かくはんのために外径 $0.35 \mathrm{~mm}$ の溶融シリカキャピラリーを全長にわたって挿入し, 適当な速度で軸を回転することによって, 反応管内を流れる液体の直径方向へのかくはんを行った。このかくはん効果により流れが栓流に近付き， 試料として注入した過マンガン酸カリウム溶液のフローシグナルのピーク形状が左右対称でシャープと なり，その改善が認められた，又，内径 $0.5 \mathrm{~mm}$, 長さ $1 \mathrm{~m}$ の反応管についてもその効果を認めた. 更 に，FIA の反応管として内径 $1.0 \mathrm{~mm}$ ，長さ $1 \mathrm{~m}$ のテフロン管を用い，鉄(III) とチオシアン酸カリウム との発色反応について検討し, 本手法が有効であることを確認した. 